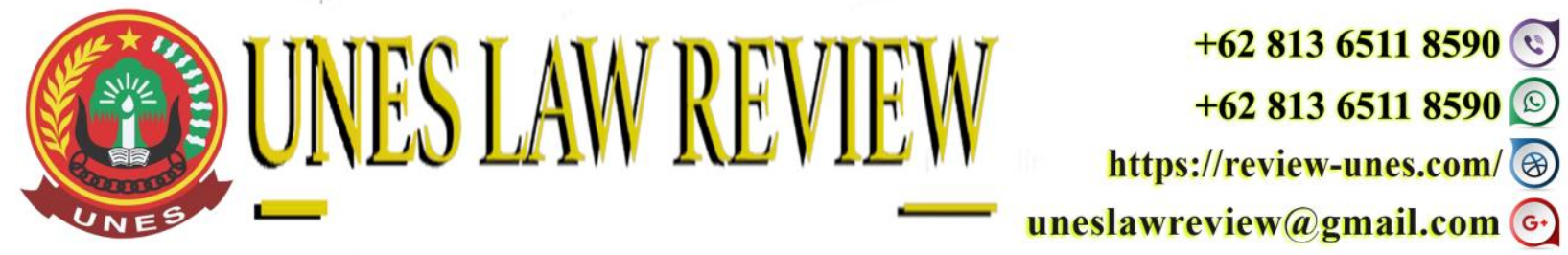

DOI: https://doi.org/10.31933/unesrev.v4i1

Diterima: 01/10/2021, Diperbaiki: 10/10/2021, Diterbitkan: 27/10/2021

\title{
OPTIMALISASI PERAN TIM SABER PUNGLI KOTA SAWAHLUNTO DALAM PENCEGAHAN PUNGUTAN LIAR DI SEKTOR PELAYANAN PUBLIK
}

\author{
Antoni Siregar \\ Program Magister Ilmu Hukum, Universitas Ekasakti, Padang, Indonesia. \\ Email: regarnaburjutfttt@gmail.com
}

Corresponding Author: Antoni Siregar

\section{ABSTRACT}

Optimization of the role of the Saber Extortion Team in Sawahlunto City in Combating Illegal Charges in the Public Service Sector has not been optimal because the perpetrators are only given a warning, not action. The role of the Saber Extortion Team is to develop an information technology-based service system to reduce the direct relationship between officers and the community. Second, the Supporting and Inhibiting Factors in the Role of the Saber Extortion Team in Sawahlunto City in Combating Illegal Charges in the Public Service Sector are law enforcement factors. There are law enforcers here, namely the Saber Extortion Task Force who act less professionally because state officials or apparatus as long as they are paid a small salary and have so much authority then illegal levies will continue. There are team members who actually also commit extortion against the perpetrators of extortion they supervise. Furthermore, the factors of facilities and facilities that affect the enforcement of illegal levies in terms of facilities or facilities are incomplete files, lack of communication between institutions, lack of facilities/facilities and the existence of side tasks for members. To support the role of the Task Force, obstacles also come from the community, namely public legal awareness, many people want to report illegal levies but they choose not to report for various reasons.

Keywords: Optimization, Role, Illegal Charges, Team Saber Extortion

\begin{abstract}
ABSTRAK
Optimalisasi Peran Tim Saber Pungli Kota Sawahlunto Dalam Penanggulangan Pungutan Liar Di Sektor Pelayanan Publik belum optimal karena pelaku hanya diberi teguran bukan penindakan. Peran Tim Saber Pungli adalah mengembangkan sistem pelayanan berbasis teknologi informasi untuk mengurangi hubungan langsung antara petugas dengan masyarakat. Kedua, Faktor Pendukung Dan Faktor Penghambat Pada Peranan Tim Saber Pungli Kota Sawahlunto Dalam Penanggulangan Pungutan Liar Di Sektor Pelayanan Publik adalah faktor Penegak hukum. Penegak hukum di sini yaitu Satgas Saber Pungli ada yang bertindak kurang
\end{abstract}


profesional di karenakan petugas atau aparatur negara selama mereka digaji kecil dan memiliki wewenang yang begitu besar maka pungutan liar akan berjalan terus. Ada anggota tim yang justru juga melakukan pungli terhadap pelaku pungli yang diawasinya. Selanjutnya Faktor sarana dan fasilitas yang mempengaruhi penegakan hukum pungutan liar dalam hal faktor sarana atau fasilitas adalah berkas yang tidak lengkap, kurangnya komunikasi antar lembaga, kurangnya sarana/fasilitas dan adanya tugas sampingan para anggota. Guna pendukung peran Satgas hambatan juga datang dari Masyarakat yaitu kesadaran hukum masyarakat, banyak masyarakat yang ingin melaporkan adanya pungutan liar tetapi mereka memilih untuk tidak melaporkan karena berbagai alasan.

Kata Kunci: Optimalisasi, Peran, Pungutan Liar, Tim Saber Pungli

\section{PENDAHULUAN}

Salah satu tugas penyelenggara pelayanan publik dalam menciptakan kesejahteraan bagi masyarakat adalah dengan memberikan pelayanan publik yang baik. Pada hakikatnya, pelayanan publik adalah pelayanan prima kepada masyarakat sebagai implementasi dari kewajiban aparatur pemerintah dalam mengabdi kepada masyarakat. Lembaga Adminsitrasi Negara mendefinisikan pelayanan umum sebagai segala bentuk kegiatan pemberian layanan yang dilaksanakan oleh instansi kepemerintahan dalam bentuk barang dan jasa, baik dalam rangka memenuhi kebutuhan masyarakat maupun dalam rangka pelaksanaan ketentuan peraturan perundang-undangan (Eko Handoyo, 2013:168).

Institusi pelayanan publik merupakan suatu instansi yang memiliki hubungan langsung dengan masyarakat, maka penyelenggara pelayanan publik perlu melakukan perubahan untuk membenahi citra negatif yang selama ini telah melekat dalam benak masyarakat. Opini negatif dari masyarakat tentang kinerja penyelenggara pelayanan publik yang hingga saat ini masih terjadi yaitu pemberian layanan yang tidak efisien dan berbelit-belit sehingga dapat memberikan kesempatan bagi oknum-oknum tertentu baik penyelenggara pelayanan publik maupun masyarakat untuk melakukan praktik pungutan liar. Pungutan liar adalah pemberian sesuatu baik berupa uang maupun benda serta fasilitas tertentu terhadap oknum-oknum pemerintah maupun oknum yang bernaung di bawah suatu organisasi atau kelompok secara langsung dengan adanya tujuan tertentu yang tidak dilandasi suatu aturan legal yang mengaturnya (Ibrahim Hot, 2017:9). Pada hakikatnya, pungutan liar atau pungli adalah interaksi antara petugas dengan masyarakat yang didorong oleh berbagai kepentingan pribadi untuk menguntungkan diri sendiri.

Maraknya kasus pungutan liar yang terjadi di Indonesia telah merusak sendi kehidupan bermasyarakat, berbangsa dan bernegara. Guna meningkatkan efektivitas pemberantasan pungli, pada tanggal 20 Oktober 2016, Presiden mengeluarkan Peraturan Presiden Nomor 87 Tahun 2016 tentang Satuan Tugas Sapu Bersih Pungutan Liar dengan menunjuk Menteri Koordinator Bidang Politik, Hukum dan Keamanan untuk mengendalikan dan bertanggung jawab terhadap kegiatan Satgas Sapu Bersih Pungutan Liar. Pembentukan Satuan Tugas Sapu Bersih Pungutan Liar merupakan langkah tegas dan wujud nyata pergerakan pemerintah dalam menanggulangi praktik pungutan liar yang bertujuan untuk memulihkan kepercayaan publik, memberikan keadilan dan kepastian hukum bagi masyarakat. 
Berdasarkan Pasal 2 Peraturan Presiden Nomor 87 Tahun 2016 dijelaskan bahwa Satuan Tugas Sapu Bersih Pungutan Liar bertugas melaksanakan pemberantasan pungutan liar secara efektif dan efisien dengan mengoptimalkan pemanfaatan personil, satuan kerja dan sarana prasarana, baik yang berada di Kementerian/Lembaga maupun Pemerintah Daerah. Ditetapkannya Peraturan Presiden Nomor 87 Tahun 2016 ini sebagai pedoman bagi pemerintah baik di tingkat Pusat, Provinsi, maupun Kabupaten/Kota di seluruh wilayah Indonesia untuk membentuk Satuan Tugas Sapu Bersih Pungutan Liar.

Pungutan liar secara umum yaitu kegiatan meminta sejumlah uang atau barang yang dilakukan dengan tidak tertata, tidak berizin resmi dan dilakukan secara sembunyi-sembunyi dari aparat penegak hukum. Selain itu, pungutan liar adalah segala bentuk pungutan tidak resmi yang tidak mempunyai landasan hukum, sehingga tindakan pungutan tersebut dinamakan sebagai pungutan liar yang mana pelaku pungutan liar selalu diikuti dengan tindakan kekerasan atau ancaman terhadap korban. Sehingga, dapat dikatakan bahwa pungutan liar merupakan tindakan pemerasan sedangkan dalam hukum pemerasan merupakan tindak pidana (Jh Wempie Kumendong, 2017:5).

Praktik pungutan liar yang dilakukan oleh oknum-oknum yang tidak bertanggung jawab untuk mencari keuntungan bagi dirinya sendiri dalam suatu pelayanan publik menjadi citra negatif bagi masyarakat. Praktik pungutan liar tentu telah membawa kerugian bagi masyarakat, terutama bagi masyarakat yang pernah menjadi korban pungutan liar. Oleh karena itu, untuk menciptakan wilayah Kota Sawahlunto yang bersih dan aman dari praktik pungutan liar, maka dibentuklah Satgas Saber Pungli kota Sawahlunto.

Salah satu kasus yang terjadi di Sawahlunto adalah pungutan liar yang dilakukan seorang Kepala sekolah terhadap guru gurunya. Pungutan dilakukan setiap para guru di sekolah tersebut mendapatkan uang tunjangan sertifikasi guru. Kasus lain adalah pada pelayan kependudukan yaitu pembuatan Kartu Tanda Penduduk dan kartu keluarga pada dinas kependudukan dan catatan sipil kota Sawahlunto.

Permasalahan yang akan dibahas adalah optimalisasi peran Tim Saber Pungli Kota Sawahlunto dalam penanggulangan pungutan liar di sektor pelayanan publik.

\section{METODE PENELITIAN}

Spesifikasi penelitian adalah deskriptif analitis, dengan metode pendekatan yuridis normative didukung oleh yuridis empiris. Jenis data yang digunakan adalah data sekunder dan data primer. Data sekunder diperoleh dari studi dokumen, data primer diperoleh dengan cara wawancara. Data yang diperoleh kemudian dianalisa secara kualitatif .

\section{HASIL DAN PEMBAHASAN}

Optimalisasi Peran Tim Saber Pungli Kota Sawahlunto Dalam Penanggulangan Pungutan Liar Di Sektor Pelayanan Publik

Upaya untuk mengatasi permasalahan mengenai pungli di Iindonesia, Menko Polhukam mengumumkan pembentukan Satgas Satuan Sapu Bersih Pungli, yang dibentuk berdasarkan Peraturan Presiden (Perpres) Nomor 87 Tahun 2016 tentang Satuan Tugas Sapu Bersih Pungutan 
Liar. Dalam melaksanakan tugasnya Saber Pungli berada di bawah koordinasi Menko Polhukam. Satgas Satuan Sapu Bersih Pungli bertugas untuk memberantas praktik pungli secara efektif dan efisien. Caranya, dengan mengoptimalkan pemanfaatan personel, satuan kerja dan sarana prasarana, baik yang berada di kementerian/lembaga atau pemerintah daerah. Satgas itu memiliki empat fungsi, yakni intelijen, pencegahan dan sosialisasi, penindakan, serta yustisi. Selain itu, satgas Satuan Sapu Bersih Pungli juga berwenang melakukan operasi tangkap tangan (Wisnu Wardhana, Ida Lestiawati, Abd. Malik Bram, 2019:95).

Satgas Saber Pungli mempunyai tugas melaksanakan pemberantasan pungutan liar secara efektif dan efisien dengan mengoptimalkan pemanfaatan personil, satuan kerja, dan sarana prasarana, baik yang berada di kementerian/lembaga maupun pemerintah daerah. Dalam berorganisasi, satgas saber pungli memiliki visi dan misi. Visi satgas saber pungli adalah terwujudnya pelayanan publik pada kementerian/lembaga dan pemerintah daerah yang terbebas dari pungutan liar, sedangkan misi satgas sebagai berikut:

1. Membangun sistem pencegahan dan pemberantasan pungutan liar

2. Membangun sistem pengumpulan, pengolahan, penyajian data dan informasi dari Kementerian/lembaga dan pihak lain yang terkait dengan menggunakan teknologi informasi.

3. Membangun dan menginternalisasi budaya anti pungli pada tata pemerintahan dan masyarakat.

4. Mengoordinasikan, merencanakan dan melaksanakan kegiatan pemberantasan pungutan liar.

5. Meningkatkan kualitas pelayanan kepada publik melalui transparansi dan standarisasi pelayanan, sesuai peraturan perundang-undangan dan menghapuskan pungutan liar.

Berdasarkan data yang penulis peroleh dari hasil penelitian lapangan di kota Sawahlunto diketahui dalam mendukung peran Tim saber pungli terdapat fungsi dan prosedur atau mekanisme penanganan perkara pungutan liar yang ditangani oleh Tim Satgas Sapu Bersih Pungli pada Kota Sawahlunto, yaitu Fungsi Intelijen dengan kegiatan:

1) Melaksanakan kegiatan intelijen berupa pengumpulan data dan keterangan pengamanan, penggalangan dengan langkah-langkah deteksi, identifikasi dan penilaian dalam rangka penajaman target kegiatan, pelaku dan anatomi jaringan pelaku pungli.

2) Melaksanakan kegiatan pemetaan terhadap modus operandi yang dilaksanakan oleh oknum pelaku pungli di linkungan Kejaksaan

3) Membuat laporan perkembangan hasil penyelidikan kepada ketua pelaksana.

4) Melaksanakan pengamanan internal terhadap kegiatan penegakan hukum oleh satgas saber pungli Kejaksaan dari kemungkinan upaya yang dapat melemahkan satgas

5) Membuat analisa dan perkiraan ancaman sebelum pelaksanaan kegiatan penindakan terhadap para pelaku pungli serta tukar menukar data intelijen dengan mintra intelijen strategis.

Selanjutnya Fungsi pencegahan dengan kegiatan: 
1) Membuat produk-produk terkait dengan kempanye anti pungli, seperti pamplet, brosur, spanduk, baliho, film)

2) Menumbuhkembangkan daya cegah dan daya tangkal masyarakat terhadap pungli melalui penyertaan sikap/ikrar anti pungli pada sentra pelayanan masyarakat

3) Membangun sisten pencegahan pungli secara kompherensif

4) Membangun budaya anti pungli dalam masyarakat.

Pada tim saber pungli kota Sawahlunto terdapat juga fungsi Penindakan dengan tugas :

1) Melaksanakan kegiatan saber pungli dan operasi tangkap tangan terhadap para pelaku pungli

2) Mengamankan oknum pelaku pungli dan barang bukti terkait pungli

3) Menyerahkan hasil operasi tangkap tangan kepada Pokja Yustisi untuk dilakukan kejian

4) Menindak lanjuti hasil kajian Pokja Yustisi terhadap hasil OTT

Sedangkan Fungsi Yustisi melaksanakan:

Mempelajari, meneliti dan menganalisa hasil OTT dari pokja penindakan Membuat laporan kepada ketua pelaksana yang membuat analisa dan rekomendasi sanksi terhdap pelaku pungli.

Adapun Prosedur atau mekanisme penanganan perkara pungutan liar oleh tim saber pungli adalah:

a. Masyarakat dapat menyampaikan pengaduan atas dugaan penyimpangan yang dilakukan oleh aparatur sipil negara di instansi Daerah kepada Aparat Pengawas Internal Pemerintah dan/atau aparat penegak hukum.

b. Aparat penegak hukum melakukan pemeriksaan atas pengaduan yang disampaikan oleh masyarakat sebagaimana dimaksud setelah terlebih dahulu berkoodinasi dengan Aparat Pengawas Internal Pemerintah atau lembaga pemerintah non kementerian yang membidangi pengawasan.

Aparat Pengawasan Intern Pemerintahan APIP dalam melaksanakan pemeriksaan investigatif menemukan adanya dugaan korupsi, kemudian menyerahkan kepada Kejaksaan Atau Kepolisian untuk dilakukan penyelidikan. Terkait dengan alur peneyelidikan ideal yang dilakukan adalah berawal dari laporan hasil kegiatan Pokja intelijen tentang indikasi terjadi pungli yang telah dikaji oleh tim yustisi dengan rekomendasi untuk dilakukan penindakan sehingga kemudian tim penindakan melakukan kegiatan untuk menindak lanjuti dalam rangka pengumpulan bukti dengan tujuan untuk mendapatkan fakta terkait siapa, berbuat apa dan apa akibatnya disertai dasar hukumnya.

Faktor Pendukung Dan Faktor Penghambat Peranan Tim Saber Pungli Kota Sawahlunto Dalam Penanggulangan Pungutan Liar Di Sektor Pelayanan Publik

Soerjono Soekanto mengemukakan beberapa faktor yang mempengaruhi terhambatnya penegakan hukum diantaranya adalah:

\section{Faktor Substansi Hukum}

Faktor substansi hukum ini merupakan hasil aktual (output) yang sekaligus merupakan dasar bagi bekerjanya sistern hukum dalam kenyataan. Baik buruknya suatu substansi hukum 
tergantung kepada baik buruknya sikap para penegak hukum, sedangkan baik buruknya sikap para penegak hukum tergantung kepada baik buruknya nilai-nilai yang diterirna dan dipahami oleh para penegak hukum. Dengan dernikian, baik buruknya substansi hukum pada hakikatnya sangat ditentukan oleh baik buruknya nilai yang diterima dan dipahami oleh para penegak hukum. Jadi, sebagal hasil aktual dari bekerjanya sistem hukum, maka substansi hukum pada hakikatnya merupakan aktualisasi nilai-nilai yang diterima dan dipahami oleh para penegak hukum.

\section{Faktor Penegakan Hukum}

Fungsi hukum, mentalitas atau kepribadian petugas penegak hukum memainkan peranan penting, kalau peraturan sudah baik, tetapi kualitas petugas kurang baik ada masalah. Oleh karena itu, salah satu kunci keberhasilan dalam penegakan hukum adalah mentalitas atau kepribadian penegak hukum.

\section{Faktor Sarana atau Fasilitas Pendukung}

Faktor sarana atau fasilitas pendukung mencakup perangkat lunak dan perangkat keras, salah satu contoh perangkat lunak adalah pendidikan. Pendidikan yang diterima oleh Polisi dewasa ini cenderung pada hal-hal yang praktis konvensional, sehingga dalam banyak hal polisi mengalami hambatan di dalam tujuannya, diantaranya adalah pengetahuan tentang kejahatan komputer, dalam tindak pidana khusus yang selama ini masih diberikan wewenang kepada jaksa, hal tersebut karena secara teknis yuridis polisi dianggap belum mampu dan belum siap. Walaupun disadari pula bahwa tugas yang harus diemban oleh polisi begitu luas dan banyak.

\section{Faktor Masyarakat}

Penegak hukum berasal dari masyarakat dan bertujuan untuk mencapai kedamaian di dalam masyarakat. Setiap warga masyarakat atau kelompok sedikit banyaknya mempunyai kesadaran hukum, persoalan yang timbul adalah taraf kepatuhan hukum, yaitu kepatuhan hukum yang tinggi, sedang, atau kurang. Adanya derajat kepatuhan hukum masyarakat terhadap hukum, merupakan salah satu indikator berfungsinya

\section{Faktor Kebudayaan}

Berdasarkan konsep kebudayaan sehari-hari, orang begitu sering membicarakan soal kebudayaan. Kebudayaan menurut Soerjono Soekanto, mempunyai fungsi yang sangat besar bagi manusia dan masyarakat, yaitu mengatur agar manusia dapat mengerti bagaimana seharusnya bertindak, berbuat, dan menentukan sikapnya kalau mereka berhubungan dengan orang lain. Dengan demikian, kebudayaan adalah suatu garis pokok tentang perikelakuan yang menetapkan peraturan mengenai apa yang harus dilakukan, dan apa yang dilarang (Soerjono Soekanto, 2004:42).

Berdasarkan data yang penulis peroleh dari hasil penelitian lapangan di kota Sawahlunto diketahui beberapa faktor yang menjadi kendala penyelenggaraan operasional Tim Saber Pungli diantaranya faktor Penegakan Hukum. Penegak hukum di sini yaitu Satgas Saber Pungli ada yang bertindak kurang profesional di karenakan petugas atau aparatur negara selama mereka 
digaji kecil dan memiliki wewenang yang begitu besar maka pungutan liar akan berjalan terus. Ada anggota tim yang justru juga melakukan pungli terhadap pelaku pungli yang diawasinya.

Faktor sarana dan fasilitas yang mempengaruhi penegakan hukum pungutan liar dalam hal faktor sarana atau fasilitas adalah berkas yang tidak lengkap, kurangnya komunikasi antar lembaga, kurangnya sarana/fasilitas dan adanya tugas sampingan para anggota. Berbagai permasalahan yang telah diuraikan di atas menyebabkan kinerja Satuan Tugas Sapu Bersih Pungutan Liar di Kota sawahlunto tidak bekerja dengan maksimal jadi mempengaruhi kurang efektifnya penegakan hukum kasus pungutan liar di Kota sawahlunto.

Faktor Masyarakat atau Faktor kultural yaitu kesadaran hukum masyarakat membantu pelaksanaan atau penegakan hukum pada suatu negara dengan mulus, banyak masyarakat yang ingin melaporkan adanya pungutan liar tetapi mereka memilih untuk tidak melaporkan karena berbagai alasan. Faktor Kebudayaan juga sangat mempengaruhi efektivitas penanggulangan tindak pidana pungutan liar, masyarakat menganggap suap atau pungutan liar adalah hadiah atau tanda terima kasih, yang kemudian pemikiran yang seperti itu telah menjadi budaya di dalam kehidupan masyarakat di Indonesia.

\section{KESIMPULAN}

Penigkatan mental aparat penegak hukum dalam memberantas pungli dengan pendidikan dan kejuruan, sehingga bukan malah ikut menjadi pelaku pungli. Agar Lebih dilengkapinya sarana dan prasarana serta ditingkatkannya komunikasi antar lembaga anggota Satgas Saber pungli sehingga dapat dilakukan optimalisasi peran dari satgas tersebut.

\section{DAFTAR PUSTAKA}

Eko Handoyo, Kebijakan Publik, Widya Karya, Semarang, 2013

Ibrahim Hot, Rahasia Dibalik Sapu Bersih Pungli, Deepublish, Yogyakarta, 2017

Jh Wempie Kumendong, Kajian Hukum Tentang Satuan Tugas Sapu Bersih Pungutan Liar Menurut Peraturan Presiden Republik Indonesia Nomor 87 Tahun 2016, Universitas Sam Ratulangi, Jurnal Lex Privatium, Vol. V. No. 2, 2017

Wisnu Wardhana, Ida Lestiawati, Abd. Malik Bram, 2019, Pemberantasan Pungutan Liar Sebagai Tidak Pidana Oleh Satuan Tugas Sapu Bersih, Palu, Jurnal Unismuhpalu

Menteri Koordinator Politik Hukum dan Keamanan, Buku Panduan Satuan Tugas Sapu Bersih Pungutan Liar, Menkopolhukam, 2016

Soerjono Soekanto, Faktor-Faktor Yang Mempengaruhi Penegeakan Hukum. Cetakan Kelima, Raja Grafindo Persada, Jakarta, 2004 